\title{
"Economics of Share-Cropping in Haryana (India) Agriculture" - A Comment
}

\author{
ABDUL SALAM*
}

Economic efficiency of agriculture in developing countries has been a matter of great interest among the development economists and has received considerable attention in the literature on agricultural development. The increasing access to electronic computers and availability of farm management data have provided further impetus to the empirical analysis and comparison of economic efficiency among well-defind farm groups and a rich body of literature on the subject appeared during the Sixties and Seventies $[2 ; 3 ; 4 ; 6 ; 7 ; 8 ; 10 ; 11 ; 12 ; 13 ; 14$ and 15$]$. "Economics of Share Cropping in Haryana (India) Agriculture" by F. S. Bagi, published in the Spring 1981 issue of this Review [1], is a recent contribution to the literature dealing with economic efficiency of agriculture. Analysing data from a survey of 119 farms from Haryana (India), the author concludes that technical efficiency of the share-cropping farms is lower and there is significant allocative inefficiency on share-cropping and owner-operated farms. The contribution, though analysing an important issue of Haryana agriculture, however, suffers from some serious methodological problems and faulty interpretation of some of the empirical results. The 119 survey farms on which Bagi's analysis is based, had the following irrigation pattern: 20 farms fully irrigated, 17 farms totally unirrigated and remaining 82 farms partly irrigated. It is not clear from the study how the sample farms were selected, what sampling procedure was followed in choosing these farms, and how closely the "Sample farm groups" represented the actual farming situation in Haryana. Therefore, one does not know whether the results can be generalised to Haryana situation or not.

Moreover, the treatment of the farms which were partly irrigated is interesting. The author has treated irrigated and unirrigated parts of the same farm as two separate farms. The author justifies his treatment of 82 partly irrigated and unirrigated farms as two separate groups by arguing that information about output and inputs had been collected separately for the irrigated and unirrigated parts of the

* The author is Senior Research Economist at the Pakistan Institute of Development Economics, Islamabad. 
same farms. It is a well-known fact that farmers in developing countries seldom maintain detailed farm enterprise accounts. The fact that detailed enterprise information, separately for the irrigated and unirrigated parts of the farming business, was available reflects that this must be a very special group of farmers, highly educated and well versed in keeping detailed farm management accounts, who thus cannot be representative of the farmers at large. Even for such a special group, it would have been interesting to know about the treatment and apportionment of family and permanent hired labour, working livestock, capital equipment, farm implements and other such equipment between the irrigated and unirrigated parts of the farms as the farmers maintain these at the farm level and not separately for irrigated and unirrigated parts of the farm. These data are later used for estimating coefficients of production function to analyse the economic efficiency of various farm groups. As the estimated parameters of production function are sensitive to the values of these data, some explanation about the allocation of these factor inputs between the irrigated and unirrigated parts of the farming business was called for. In the absence of such information, it is not clear whether the differences in efficiency are the real differences or they can be atrributed to the allocation of inputs to various farms by the author. However the author has ignored these issues. In studying economic efficiency in general and the allocative efficiency in particular, where management plays crucial role, the treatment of the sub parts of a farm under same management as separate farms is debatable.

The author in the introductory section has argued that voluntary share-cropping prevails primarily due to two reasons: (1) there are small farmers who are unable to produce income sufficient for family needs from their own land, and in the absence of gainful off-farm employment opportunities, they must find additional land to operate; and (2) due to legislative measures and improved agricultural technology, share-cropping may have become efficient tenure system, at least in India. However, the author has completely ignored the fact that share-cropping in developing countries may also be due to the excessive population pressure on farm land and subsequent fragmentation of farm holdings. The owners of these fragments, which are scattered around, may find it economical to rent out some of their fragments at distant places and rent in, on share-cropping basis, land adjoining their farms. At the same time, some of the owners of these small holdings, which cannot support their families, shift to urban areas for non-farm employment and lease out their land for share-cropping. The owners of these small holdings may not like to dispose of their land for various social and cultural reasons.

The gross farm income from area owned on share-cropped and owner-operated farms is presented in Table 2. From these data the distribution of share-cropping and owner-operated farms, according to various income groups, is compared and some confusing and misleading inferences are drawn. The author alleges that about 80 percent of the share-cropping farms and only 45 percent of the owner-operated farms have gross income below 10,000 rupees. The average gross income of all the 119 farms in the sample is Rs. 11,805. Therefore, the author concludes that a relatively larger percentage of the share-cropping farms obtain lower income as compared to the owner-operated farms. The motivation of this comparison is not clear at all. As the share-croppers were relatively small farmers, it is no wonder that they had lower farm incomes. However, what is confusing about all this comparison is that while making the gross income comparisons in Table 2, the author is talking of income from owned area only and ignores the income of share-croppers from the land they rent in. The share-croppers are called share-croppers because they rent in, on share-cropping basis, land owned by others. They do so to supplement their meagre incomes from their own small holdings. The author has ignored this part of their farming operations and compares income from owned area only which understates their gross farm income. Therefore, the income comparison and the conclusions following from that comparison are not valid at all.

In the absence of gainful off-farm employment opportunities, the use of market wage rates for family labour is likely to over-estimate the costs and accordingly result in lower net incomes [9]. How these costs were estimated is no where spelled out. An important factor accounting for relatively lower net income on share-cropping farms (Table 3 ) may be the use of market wage rates for the greater use of family labour on share-cropping farms.

Per hectare values of output and variable inputs on owner-operated and sharecropped farms are compared in Table 5. From these data, the author infers that share-croppers use higher amounts of human and bullock labour but consistently use lower amounts of fertilizer, irrigation, capital and other expenses, which may be due to lack of cash. From the values provided in Table 5, it appears that all the groupings tried out of the sample farms had negative income as the output values given in the first row of Table 5 are very small as compared to the input expenditures for various inputs. In fact the output values (rupees per hectare) are too small to be true. How far the differences in the use level of various inputs are real and whether these difference are significant, we do not know. However, from the available data in Table 5 , there does not appear any systematic difference, and whatever the direction of these differences the differences in most of the cases are negligible. The important differences, however, appear in the use level of fertilizers and capital inputs. These differences are attributed to the lack of cash with share-croppers, without substantiating the argument with factual information. The lower use level of fertilizers on these farms may also be due to market imperfections as factor markets in developing countries in general and for commercial inputs like fertilizers in particular are known to be imperfect and favour influential farm groups [5]. The lower use of fertilizer on share-cropping farms could also be due to their ignorance about the usefulness of these materials, for, as is well known, extension services in developing countries are inadequate and often concentrate on influential farm groups. The apparent 
differences in the irrigation expenses may really be beyond the farmers' control as the access to irrigation by canals is beyond the control of individual farmers. Other differences on this account may also stem from the uncertainty surrounding the share-cropping farming. Therefore, to suggest that share-cropping farmers were lagging behind in investing on these inputs would be untrue.

Section 4 (Comparative Economic Efficiency), the most important part of this paper, attempts to analyse economic efficiency of various farm groups through estimating Cobb-Douglas production functions. In this section, the author has estimated two types of functions. The dependent variable in both these functions is the value of the crops and crop byproducts per farm. The independent variables include land, labour, fertilizers, irrigation, capital and other expenses. The function used to estimate the returns to scale includes land per farm and other variables mentioned above are defined on per-hectare basis on various farms. In the other function which is used to estimate the technical and allocative efficiency the variables are specified on per-farm basis.

There are some serious specification problems in the estimated equations. The use of gross value of production of various crops grown on farm as the dependent variable in production function estimation from cross-section data implicitly assumes that crop composition of total production is similar for various farms, whereas there is evidence (Table 4) of crop composition differences among various farm groups; i.e. owner-operated, share-cropping and irrigated farms followed different cropping patterns. Under such circumstances, crop composition effect is likely to bias the results in an unknown direction [2]. The dependent variable is the value of crops and crop byproducts. It is not clear how various byproducts, which are normally consumed at the farm, were priced and whether farm specific prices were used to estimate the overall value of farm crops. If they were, then in the case of substantial price variations among various farm groups, the question of analysing technical efficiency is compounded as a substantial proportion of what may be taken as technical efficiency may be on account of price variations for different farm groups. Price variations across various farm groups further compound the problem posed by different cropping patterns.

The estimating equations, by including the land area operated, which includes net sown area and fallow land - effective farm size is the area used for production and without incorporating any information about the land use intensity, assume a 100 -percent cropping intensity which is really an unrealistic assumption as the same piece of land may be used more than once. The exclusion of cropping intensity is likely to result in biased coefficients of the other variables.

The independent variables are in value terms, which implies an assumption that prevailing prices of these factor inputs (like fertilizers, manures and seeds,) were the same for all the farms. In view of the fertilizers and seed supplies falling short of demand and the prevailing market imperfections, this is a very serious assumption.
The estimating equations include land as an independent variable and the value of land rent is also included in other production expenses. What is the justification for this? It is just like including nutrient pounds of the fertilizers used and also fertilizer expenses in the production function estimation at the same time.

What the effect of farm size on production efficiency is - the two samples showed substantial variation in farm size - is not known, as the author has ignored this important factor. Other studies on Indian agriculture have shown farm size to be an important variable in affecting farm efficiency $[8 ; 14]$.

Aggregation of many inputs, such as (i) fertilizer and manures, (ii) irrigation services from canal and tubewells, pumpsets, (iii) other expenses on seed, land rent miscellaneous; reduces the usefulness of the analysis for policy prescription as one cannot know which of these inputs is overused or underused. For example, if the analysis reveals that there was an under-allocation on fertilizers variable; was this under-allocation in chemical fertilizers or in manure?

The share-cropped farms, by their very nature, were fragmented as these were primarily operated by owners of small parcels of land who also had rented in additional land on share basis. As fragmentation of land is regarded as a source of production inefficiency in Indian agriculture [2]. Therefore, not taking this factor into consideration and ignoring it in production function analysis, makes the comparison of technical efficiency dubious.

The technical and allocative efficiency is greatly influenced by the quality of management or, what in modern literature has been called, human capital. This variable is conspicuous by its absence throughout the discussion. The decreasing returns to scale observed in the study may be due to omission of such variables.

In view of the limitations of both data and analysis discussed above, the author's conclusion about lower efficiency of share-cropping in Haryana agriculture is hard to accept.

The section dealing with returns-to-scale function, its estimation and the discussion which follows seems redundant as the information about the returns to scale could have been easily obtained from the functions which have been estimated to compute marginal value products of various inputs.

\section{REFERENCES}

1. Bagi, F.S. "Economics of Share-Cropping in Haryana (India) Agriculture". Pakistan Development Review. Vol. XX, No. 1. Spring 1981.

2. Bardhan, P. K. "Size, Productivity and Returns to Scale: An Analysis of Farm Level Data in Indian Agriculture". Journal of Political Economy. Vol. 81, No. 6. November-December 1973.

3. Barnum, H. N. and Lyn Squire. "Technology and Relative Economic Efficiency”. Oxford Economic Papers. Vol. 30, No. 2. July 1978. 
4. Desai, B. M. "Economics of Resource Use on Sample Farms of Central Gujrat”. Indian Journal of Agriculture Economics. Vol. XXVIII, No. 1. January-March 1973.

5. Falcon, Walter P. "The Green Revolution: Generations of Problems". American Journal of Agricultural Economics. Vol. 52, No. 5, December 1970.

6. Khan, Mahmood Hassan. "Farm Size and Land Productivity Relationships in Pakistan". Pakistan Development Review. Vol. XVIII, No. 1. Spring 1979.

7. Khan, M. H., and Dennis R. Maki. "Effects of Farm Size on Economic Efficiency: The Case of Pakistan". American Journal of Agricultural Economics. Vol. 61, No. 1. February 1979.

8. Lau, Lawrence, and P. A. Yotopoulos. "A Test for Relative Efficiency and an Application to Indian Agriculture". American Economic Review. Vol.61, No. 1. 1971.

9. Paglin, Morton. "Surplus" Agricultural Labor and Development: Facts and Theories. American Economic Review. Vol. 55, No. 4. September 1965.

10. Sahota, Gian S. "Efficiency of Resource Allocation in Indian Agriculture". American Journal of Agricultural Economics. Vol. 50, No. 3. August 1968.

11. Salam, Abdul. "Resource Productivity in the Punjab's Agriculture". Pakistan Development Review. Vol. XV, No. 2. Summer 1976.

12. Sidhu, Surjit S. "Economics of Technical Change in Wheat Production in the Indian Punjab". American Journal of Agricultural Economics. Vol. 56, No. 2. May 1974.

13. Yotopoulos, P. A. Allocative Efficiency in Economic Development: A Cross Section Analysis of Epirus Farming. Athens: Center of Planning and Economic Research. 1967.

14. Yotopoulos, P. A., and Lawrence J. Lau. "Resource Use in Agriculture: Application of the Profit Function to Selected Countries". Food Research Institute Studies. Vol. XVII, No. 1. 1979.

15. Yotopoulos, P. A., and Lawrence J. Lau. "A Test of Relative Efficiency: Some Further Results". American Economic Review. Vol. 63, No. 1. 1973. 